\title{
Renomedullary Interstitial Cell
}

National Cancer Institute

\section{Source}

National Cancer Institute. Renomedullary Interstitial Cell. NCI Thesaurus. Code C159218.

A cell located in the inner renal medulla. It expresses receptors for vasoactive peptides. 